\title{
Aktivasi Psikologi Kognitif Melampaui Kesepian dengan Perspektif Komunikasi dalam Film Joker
}

\author{
Yohanes Probo Dwi Sasongko ${ }^{1}$, Joshua Fernando ${ }^{2}$, Rustono Farady Marta ${ }^{3}$ \\ Program Studi Ilmu Komunikasi, Univeritas Bunda Mulia ${ }^{1}$ \\ Falkutas Ilmu Komunikasi, Universitas Mpu Tantular ${ }^{2}$ \\ Program Studi Magister Ilmu Komunikasi, Universitas Bunda Mulia ${ }^{3}$ \\ Email: yprobo@bundamulia.ac.id
}

\begin{abstract}
ABSTRAK
Perkembangan kognitif pada dasarnya merupakan bagian dari perkembangan karakteristik manusia yang penting untuk dipahami. Ditengah laju tertumbuhan teknologi perkembangan kognitif manusia justru jatuh dan semakin terpuruk pada rasa tidak peduli terhadap sesama. Manusia terpuruk didalam rasa ketidakadilan terhadap perlakuan dalam hidupnya dan ditengah itu semua, manusia tersandera serta tidak bisa mengelak dan menghindar dari rasa kesepiannya. frekuensi laju dan gerak pertumbuhan pengetahuan yang semakin tinggi tidak diimbangi oleh kecakapan dan kepandaian manusia dalam mengelola kesepian yang menghinggapinya. Akhirnya, apa yang terjadi dalam hidupnya tidak dapat di pahami sebagai yang baik sekaligus tidak menjadi penawar serta daya sembuh yang optimal ketika manusia mengalami kesepian dalam hidupnya. Film Joker karya Todd Phillpis menjadi salah satu cerminan bahwa ditengah arus kemajuan teknologi, pertumbuhan ekonomi yang semakin dirasa sulit. Manusia kerap mengalami degradasi dalam moralitas. Ketika manusia tidak mampu mengenal dekat mengenai kesepiannya, tindakan pelepasan, pelarian dan pelampiasannya dapat dilakukan secara tidak wajar dan manusiawi. Jalan tengah yang dapat menjadi solusi adalah mengenali dan menyadari diri sendiri dengan utuh. Menerima dan mengakui dan berdamai dengan diri sendiri. Menyadari dan bersikap terbuka terhadap diri sendiri merupakan keutamaan yang harus dipahami dalam proses psikologi kognitif individu.
\end{abstract}

Kata Kunci: Melampaui; Psikologi Kognitif; Kesepian; Joker; Arthur

\section{Activation of Cognitive Psychology Beyond Loneliness within Communication Perspective in Joker Films}

\section{ABSTRACT}

Cognitive development is part of the development of human characteristics that are important to understand. During the growth rate of human cognitive development technology, it falls and is getting worse in the sense of ignoring others. Humans plummeted in a sense of injustice against the treatment in his life and the midst of it all, humans are held hostage and cannot avoid and avoid their loneliness. the higher frequency and rate of growth of knowledge is not matched by the skill and intelligence of humans in managing the loneliness that afflicts it. Finally, what happens in his life cannot be understood as being good and not being an antidote and optimal recovery when humans experience loneliness in their lives. Todd Phillips's Joker film is a reflection that amid technological advances, economic growth is increasingly difficult. Humans often experience degradation in morality. When humans are not able to know closely about their loneliness, the act of release, escape and impingement can be done unnaturally and humanly. The middle way that can be a solution is to recognize and realize yourself intact. Accept and acknowledge and make peace with yourself. Being aware and being open to yourself is a virtue that must be understood in the cognitive psychology process of the individual.

Keywords: Beyond; Cognitive Psychology; Lonely; Joker; Arthur 
Korespondensi: Yohanes Probo Dwi Sasongko, S.S., M.Pd., M.I.Kom. Universitas Bunda Mulia. Jl. Lodan Raya, RT.12/RW.2, Ancol, Kec. Pademangan, Jakarta Utara, DKI Jakarta 14430. No. HP, WhatsApp: 081808385884 Email:yprobo@bundamulia.ac.id

\section{PENDAHULUAN}

Perkembangan serta kemajuan ilmu pengetahuan dan teknologi telah menghantar dan menghadirkan dampak perubahan cara berkomunikasi dalam kehidupan manusia (Kristiyono \& Sirikit, 2019:160). Namun, perlu disadari, laju pertumbuhan pengetahuan yang semakin tinggi tidak dapat menjadi penawar ketika manusia mengalami kesepian dalam hidupnya.

Rubiyanto (2018:84) mengulas mengenai pasar audiens menjadi penting dalam kinerja media, seperti yang dikatakan bahwa kinerja media dalam satu pasar (audiens) dapat memengaruhi kinerja pasar lain (pengiklan), tetapi dengan hadirnya film Joker karya Todd Phillips yang dirilis 2 Oktober 2019 yang lalu (sinema.com). munculnya film tersebut ketengah masyarakat, merupakan kontardiksi dari laju pertumbuhan pengetahuan serta degradasi moralitas manusia terhadap sesamannya.

Masa kecil Joker yang sering disiksa oleh ayahnya mempengaruhi pola pikirnya saat ini. Dalam film tersebut, ditampilkan, bahwa dalam kondisi penyakit kejiwaan yang dialami oleh Arthur, membuatnya sulit untuk dapat mengendalikan diri terhadap lingkungan disekitarnya. Terhadap rekan- rekan kerja, serta orang- orang yang menjalin komunikasi dengannya. Terutama ketika ia merasa diperlakukan tidak baik oleh mereka yang berada disekitarnya, pun oleh Ibunya sendiri yang tengah mengalami penyakit delusi (Prasetya, 2012:77).
Penyakit mental yang diderita oleh pemeran tokoh utama dalam film tersebut, dalam kehidupan nyata dikenal dengan Pseudobulbar affect (PBA), yaitu penyakit kejiwaan dimana hal ini dapat terjadi pada penderita yang tidak dapat mengontrol tindakan tertawa pada saat ia mengalami depresi. Penyakit ini dapat membuat penderita tertawa pada saat yang tidak tepat.

Menurut sejumlah informasi yang dapat dipelajari lebih lanjut, penyakit kejiwaan seperti Pseudobulbar affect, ditenggarai karena beberapa faktor. Indikasi yang dapat dipahami, timbulnya penyakit mental ini, disebabkan oleh adanya kerusakan pada korteks prefrontal yaitu area otak yang membantu mengendalikan emosi yang meletup- letup pada dirinya. Sehingga, kemudian secara tidak sadar ia melakukan tindakantindakan yang dianggap aneh oleh orang disekitarnya, seperti tertawa pada saat yang tidak tepat. Perbuatan menangis, marah- marah pada saat yang tidak baik (Ahmed \& Simmons, 2013:483).

Penyakit mental yang dialami oleh Arthur serta pengalaman- pengalaman trauma yang dialami masa lampau terhadap dirinya. Ditambah penyakit mental yang dideritanya sepertinya sulit untuk diobati dan dimaafkan. Oleh karena itu, Pengalaman dan derita yang dialaminya, membawa pada rasa kesepian pada dirinya.

Orang yang kesepian merasa terasing dari kelompoknya, tidak merasakan hangatnya cinta pada orang di sekelilingnya. Mereka merasa, tidak ada yang peduli dengan dirinya dan merasakan 
kesendirian, serta merasa sulit untuk mendapatkan teman (Nurayni \& Supradewi, 2017:35). Kesepian cenderung untuk menjadi tidak bahagia dan tidak puas dengan diri sendiri, tidak mau mendengar keterbukaan intim dari orang lain dan cenderung tidak membuka diri, merasakan kesia-siaan (hopelessness), dan merasa putus asa.

Dalam beberapa pemahaman, Kesepian merupakan pengalaman emosional yang tidak menyenangkan yang dihasilkan dari tingkat memadai atau rendahnya kualitas hubungan sosial. Kesepian dijelaskan sebagai sebuah sebuah perasaan yang umum terjadi pada seseorang. Perasaan tersebut kompleks dan unik pada setiap individu. Bisa di gambarkan sebagai seorang anak yang sedang berjuang untuk menjalin pertemanan di lingkungan sekolahnya mempunyai kebutuhan yang berbeda dengan seorang dewasa kesepian yang baru saja ditinggal meninggal oleh pasangannya (Hidayati, 2015:155).

Dalam kesepian yang ia alami, ada trauma dan luka batin pada hidupnya yang sulit untuk dikomunikasikan dengan dirinya. Kondisi ini diperparah dengan sikap Ibunya yang selalu mengalami delusi tentang kehidupan masa lalunya. Lebih lanjut, efek yang mungkin terjadi atas ketidak mampuan dalam mengatasi penyakit kejiwaan tersebut adalah dengan melakukan tindakan- tindakan yang agresif terhadap lawan bicara dan orang- orang disekitarnya. Pelarian dalam bentuk menyakiti sesamanya. Peristiwa dan kejadian yang dialami oleh Arthur, membawa dirinya menjadi sulit membangun komunikasi dengan orang lain, terutama bagaimana ia dapat mengolah dan merepresentasikan dirinya berhadapan dengan tindakan- tindakan yang berhubungan dengan proses psikologi kognitif yang harus ia bangun dengan dirinya sendiri.

Perkembangan kognitif identik dengan perkembangan intelektual atau intelegensi. Perkembangan kognitif manusia adalah proses psikologis yang melibatkan keseluruhan proses dalam memperoleh pengetahuan, menyusun dan menerapkan pengetahuani layaknya berfikir, mengingat, memahami, menimbang, mengamati, menganalisis, mensintesis, mengevaluasi dan memecahkan masalah melalui interaksi sosial yang terjadi di lingkungan sekitar (Arifin, 2016: $51)$.

Terdapat sebuah proses informasi yang di olah dalam pemikiran manusia yang di namakan psikologi kognitif. Dalam proses psikologi kognitif, informasi yang diterima berupa data yang mudah di ingat dan memberikan dampak yang besar pada perkembangan manusia. Hal ini disebut dengan kata kunci "mudah di ingat" yang dapat mempermudah recall memory sehingga secara cepat manusia dapat mendeteksi berbagai situasi kejadian yang dapat mempengaruhi pemaknaan objek sehingga muncul suatu perilaku. Keseluruhan proses seperti sensasi, persepsi, pengalaman, dan memori menjadi hal terpenting dalam proses pemokiran kognitif (Puspasari, 2014:8).

Dari definisi di atas, kita dapat menyimpulkan bahwa, komunikasi intrapersonal adalah komunikasi yang berlangsung dalam diri seseorang. Orang itu berperan baik sebagai komunikator maupun sebagai komunikan, dia berbicara pada dirinya sendiri, dia berdialog 
dengan dirinya sendiri, dia bertanya kepada dirinya sendiri, dan dijawab oleh dirinya sendiri. Apabila seseorang mampu berdialog dengan diri sendiri berarti ia mampu mengenal diri sendiri.

Penting bagi kita untuk bisa mengenal diri sendiri sehingga kita dapat berfungsi secara bebas di masyarakat. Belajar mengenal diri sendiri berarti belajar bagaimana kita berpikir, berasa, dan bagaimana kita mengamati, menginterpretasikan, dan mereaksi lingkungan kita. Oleh karena itu untuk mengenal diri pribadi, kita harus memahami dengan baik komunikasi intrapersonal. Penelitian ini ingin melihat bagaimana konstruksi komunikasi psikologi kognitif tokoh Joker sebagai usaha melampaui kesepian pada film Joker karya Todd Phillpis.

\section{METODE PENELITIAN}

Dalam penulisan karya ilmiah ini, metode yang dipakai, dengan menggunakan metode kualitatif. Kajian ini menggunakan metode literatur, terutama terkait dengan analisis pustaka serta dokumen- dokumen yang diperlukan dalam menunjang penulisan ini (Fensi, 2018). Hal- hal yang meliputi didalam analisis dokumen, yakni analisis otobiografi, memoar, catatan- catatan lepas harian, surat- surat pribadi, berita diharian, artikel didalam majalah, catatan dan berkas dipengadilan, brosur, bulletin, foto- foto dan lain sebagainya (Mulyana, 2013:195).

Analisis kritis yang dipakai sebagai mata pisau dalam penelaah lebih dalam dan menyeluruh, mengulas dan mengupas mengenai artikel- artikel yang ada diharian, majalah dan sumber- sumber literature yang tersedia dan memadai (Sasongko \& Marta, 2018).

Beberapa catatan dan temuan akan dibahas dan diperuncing dalam konteks yang disesuaikan dengan tema yang diangkat oleh penulis. Kemudian, keseluruhan kajian nantinya akan dikonektifitaskan secara diametral dengan mengambil jarak yang berbeda, dengan pemahaman masyarakat atau mereka yang melihat sisi yang tampak dalam film Joker tersebut.

Dalam proses selanjutnya, kemudian dirancang dalam sistem polarisasi sebuah jembatan yang menghuhubungkan sebuah tindakan yang dapat melahirkan pemahaman yang komprehensif. Disamping itu juga, untuk mengatasi sekaligus menemukan solusi melalui ide- ide terbaru. Sehingga pada akhirnya, kita dapat melihat sekaligus menelisik tindakan, serta perbuatan yang dapat dilakukan untuk melampaui rasa kesepian yang hinggap, dan dimiliki oleh setiap manusia (Strauss, 2015).

\section{HASIL DAN PEMBAHASAN}

Bila menyaksikan film Joker karya Todd Phillips, banyak nilai dan pesan yang dapat diambil. Film apik mengenai realitas kenyataan yang ada didalam masyarakat ini lahir dari upaya konkrit yang dilakukan oleh Arthur dalam menghidupi, mengenali dan menjejaki dirinya. Arthur adalah sosok pria yang memiliki kepribadian yang baik.

Pada adegan awal. Gambar 1, dibuka dengan menampilkan sosok Arthur yang tengah mempersiapkan diri untuk menjadi badut pada salah satu toko di tengah kota tersebut. Nampak 
pada gambar tersebut ia tengah mempersiapkan diri dengan memakai tat arias seperti badut. Namun, bila melihat lebih dalam pada tampilan gambar 1 tersebut, seolah olah sudah tampak, Arthur memendam kesepian yang dalam. Ini terlihat pada tatapan matanya yang kosong dan tidak memiliki sikap semangat kerja yang tinggi. Entah apa yang ada dibenaknya. Apa yang sedang dipikirkannya, namun hal ini menyiratkan ia mengalami kesendirian dijiwanya.

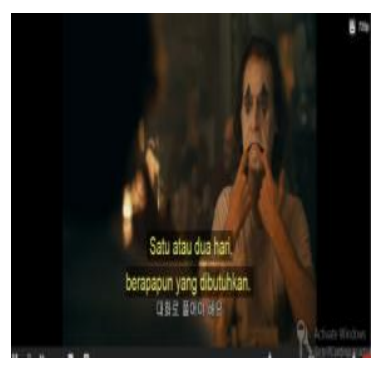

Sumber: Joker, 2019

Gambar 1. Scene 1

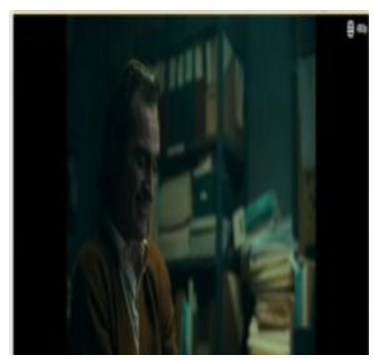

Sumber: Joker, 2019

Gambar 2. Scene 2
Pada gambar 2, dikisahkan, Arthur yang sedang mengunjungi psikiater pada dinas kesehatan dikotanya. Ditempat itu, dia berusaha untuk mengatasi derita yang dialaminya bahwa ia memiliki gangguan mental yakni penyakit yang dapat menyebabkan ia tertawa pada saat yang tidak tentu dan tidak dapat dikontrol.

Adanya ketidakteraturan, serta ketidakselarasan secara emosional inilah yang di menjadi pemicu dan pencetus hadirnya perasaan yang tidak menentu dalam hal ketidaksetabilan dalam mengelola emosiaonal secara signifikan. Perlakuan dan sikap yang tidak manusiawi terhadap joker telah meninggalkan luka dan menorehkan perasaan yang tidak menyenangkan dan perasaan terganggu di dalam diri individu yang memiliki perasaan kesepian dan hampa dalam hidupnya (Sibarani, 2013).

Selain hal tersebut, kesepian dapat memiliki dampak yang tidak baik bagi dirinya sendiri. Orang yang memiliki perasaan kesepian merasa memiliki perasaan tidak menyenangkan dan terganggu juga kerena adanya penilaian yang negatif atau ketidaksesuaian perilakunya yang dibandingkan dengan kecenderung perilaku sosial pada umumnya. Disatu sisi Joker melihat perlakuan masyarakat terhadap hidupnya diluar batas. Hal ini terlihat ketika ia di ejek dan dipukuli ketika sedang bekerja dan sekelompok anak muda mengambil papan reklame saat dia mempromosikan barang ditoko. Tidak mengherankan bahwa keadaan masyarakat yang cuek dan tak mau peduli terhadap sesamanya semakin melahirkan motivasi yang kuat untuk membalas dan menyakiti kembali perasaan kesepian yang dialaminya .

Adegan pada gambar 3, terlihat bagaimana Arthur tengah berdiskusi dengan pemimbing kejiwaanya. Namun apa yang dialaminya, dengan penyakit Pseudobulbar affect (PBA), yaitu penyakit kejiwaan yang dideritannya, sepertinya ia mengalami kesepian.

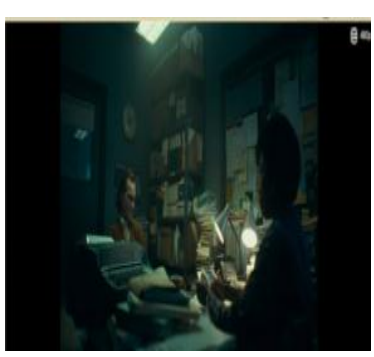

Sumber: Joker, 2019 Gambar 3 . Scene 3

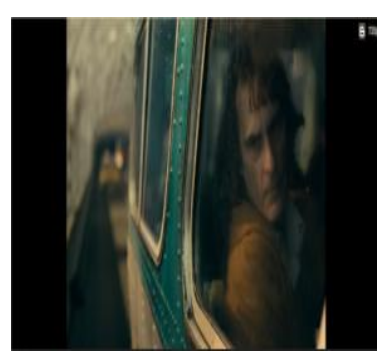

Sumber: Joker, 2019 Gambar 4. Scene 4 
Hal ini terlihat ketika informasi yang ia peroleh dari lembaga pemerintah yang menangani penyakit kejiwaan tersebut. dalam hal ini, pemerintah berencana menutup semua pembiayaan pengobatan bagi mereka atau warga masyarakat yang mengalami gangguan kejiwaan. Kondisi kejiwaan yang dilami Arthur juga dapat dialami oleh kita yang hidup dimasyarakat saat ini. Kondisi ini terjadi pada penderita yang tidak dapat mengontrol tindakan tertawa pada saat ia mengalami depresi.

Sejak kecil Arthur sudah mengalami pelbagai macam tindak kekerasan. Hal ini didapat oleh orangtua angkatnya yang kerap memperlakukan dia dengan tindakan kasar. Pelbagai kekerasan fisik dan hujatan kerap pula ia terima. Hal ini, tentu saja membuatnya mengalami depresi, ketakutan, dan kesepian yang luar biasa. Trauma dan penderitaan sudah menjadi bagian hidupnya. Siksaan orang tua, yang juga kehilangan kewarasan, mendorong Arthur berada pada pucuk ketidakmampuan mengendalikan diri dan kesepiannya. Tawa yang keluar dari wajahnya justru penuh dengan kengerian dan rasa ingin membalas dendam.

Demikian juga, pada gambar 4, tampak Arthur yang tengah putus asa untuk mengatasi kondisi kejiawaannya dan sejumlah masalah yang dihadapinya. Baik itu dalam keluarga dengan ibunya yang sakit dan mengalami delusi. Sementara itu, disatu sisi ia juga tengah mengalami masalah dengan pekerjaannya. Di tempat pekerjaannya, ia dituntut untuk bekerja dengan baik dan benar. Tidak menghilang dan harus mengembalikan papan reklame yang hilang saat dipakainya untuk promosi penjualan tersebut.

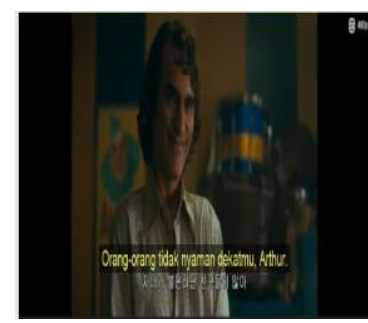

Sumber: Joker, 2019

Gambar 5. Scene 5

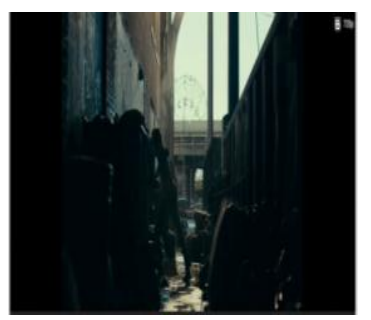

Sumber: Joker, 2019

Gambar 6. Scene 6
Potongan dalam gambar 5, memperlihatkan bahagimana didalam rasa kesepian yang dihadapinya, ia tengah memperjuangkan keberadaan dirinya agar dapat diterima oleh masyarakat. Terutama oleh pimpinan yang akan memecatnya karena ditengah kegiatannya dalam pertunjukkan badut, ia kedapan membawa senjata tajam. Tentu saja atas perbuatannya ini, pimpinan dan tempat ia melayani, yakni rumah sakit, akan menolak dia untuk bermain dan tampil kembali.

Arthur dalam keterangannya, ia melakukan membawa senjata, semata- mata untuk menjaga dirinya. Membuat dia bisa mengatasi kesepiannya. Namun, akhirnya ia tidak bisa menahan dirinya. Pada gambar 6, ia bereaksi menendang- nendang tempat sampah, sebagai penyaluran atas kekesalan dan kesepian yang dialaminya. Serta ketidakmampuan dirinya mengolah kesepian atas peristiwa yang dialaminya tersebut.

Arthur dalam penjelasan gambar ini tengah megalamin tingkat kesepian yang tinggi (Sasongko \& Marta, 2018:127). Hal ini terlihat jelas ketika dia mengalami benturan- benturan permasalahan dalam hidupnya. Sikap dan tindakan yang dilakukan untuk mengatasi kesepian dalam 
hidupnya yakni dengan melampisakan dan memukul serta menendang apa yang ada dan dekat dengan dia. Entah apapun tindakannya, sepertinya ia tidak dapat membalas dan tidak kuasa terhadap apa yang dia hadapi.

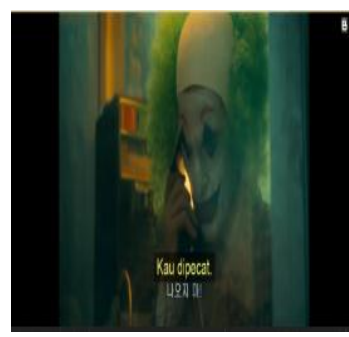

Sumber: Joker, 2019

Gambar 7. Scene 7

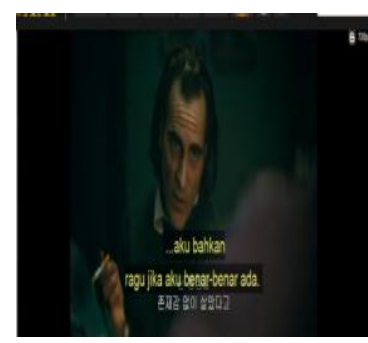

Sumber: Joker, 2019

Gambar 8. Scene 8
Pada adegan dalam gambar 7, diperlihatkan tampilan saat dia harus menerima keputusan untuk diberhentikan dengan sepihak. Maka, atas keputusan pemberhentian kerjanya, ia merasa frustasi dan bersedih. Demikian juga dalam gambar 8, pada kisah gambar tersebut, diutarakan tentang ia yang semakin tidak bisa mengatasi tekanan- tekanan yang dia dapat pasca pemecatan dirinya. Ia harus dapat membuktikan dirinya untuk mencari tahu tentang masa lalu hidupnya.

Pencaharian diri berhadapan dengan delusi yang dialami oleh ibunya. Arthur dengan segenap kemampuannya, berusaha mencari keterangan bahwa ia adalah anak dari calon walikota Thomas Wayne. ini didapat setelah ia membaca surat yang di buat oleh ibunya, (lih, Gambar 9), Penny Fleck kepada Thomas Wayne.
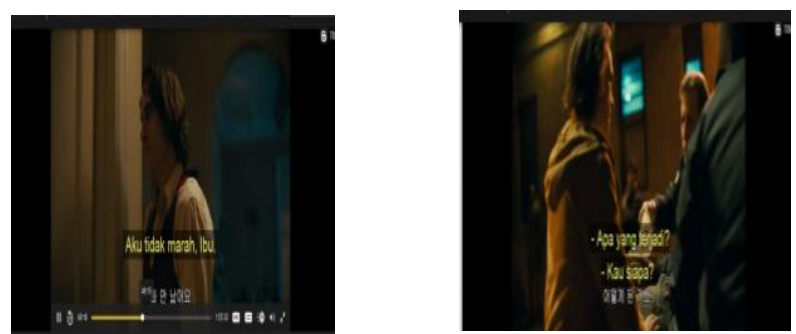

Sumber: Joker, 2019

Gambar 9 . Scene 9

Sumber: Joker, 2019

Gambar 10. Scene 10

Dalam petikan gambar 10, ditampilkan juga bagaimana Arthur ditengah kesepiannya mencari identitas tentang dirinya, ia dihadapkan pada beragam masalah kembali. Ibunya mengalami sakit dan harus dibawa kerumah sakit untuk mendapatkan perawatan yang intensif

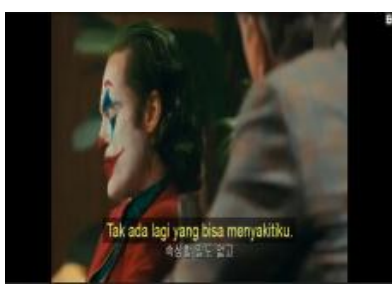

Sumber: Joker, 2019

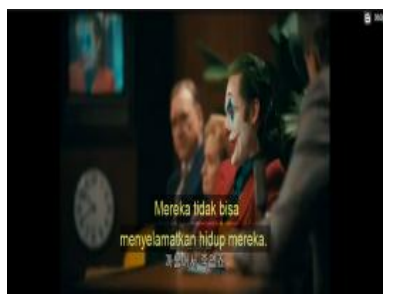

Sumber: Joker, 2019 Gambar 13 . Scene 13
Gambar 11. Scene 11

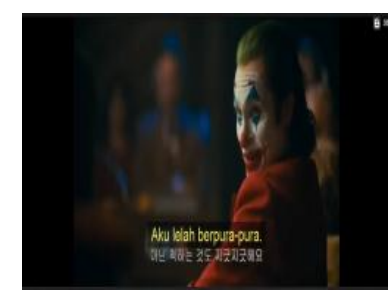

Sumber: Joker, 2019

Gambar 12. Scene 12

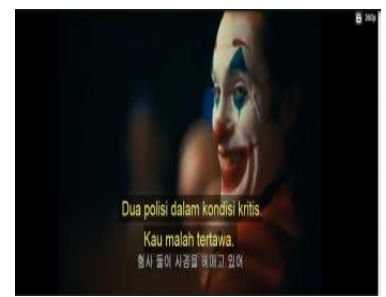

Sumber: Joker, 2019

Gambar 14. Scene 14
Pada gambar 11, kita melihat Arthur saat tampil pada acara live Murray Franklin Show, sebuah acara komedi realita tentang kehidupan (gambar 12). Tampak dalam wawancara, ia terlihat mengumpat dan menjelaskan tentang apa yang telah ia lakukan terhadap orang lain. dalam pemaparannya, Arthur sepertinya menyembunyikan kesepiannya dengan menjelaskan melalui lakon komedi (Gambar 13). Namun, ketika Murray mulai mengolok dan menghina tentang dirinya yang dianggap tidak bisa menerima kenyataan (Gambar 14), kemudian 
ia menarik sebuah senjata dan menembak Murray sampai meninggal.

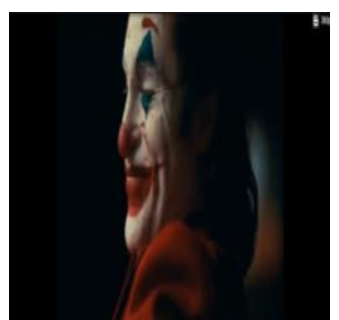

Sumber: Joker, 2019 Gambar 15. Scene 15

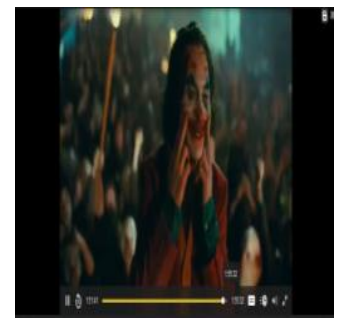

Sumber: Joker, 2019

Gambar 16. Scene 16
Kesepain yang dialami dalam hidupnya semakin tampak. Ini, tampak pada gambar 15 dan gambar 16. Saat dimana Arthur tetap terlihat tersenyum dalam tatapan yang kosong saat ia selesai membunuh Murray dan ketika ia berada ditengah kerumunan saat demonstrasi dilakukan di tengah kota Gothom tersebut.

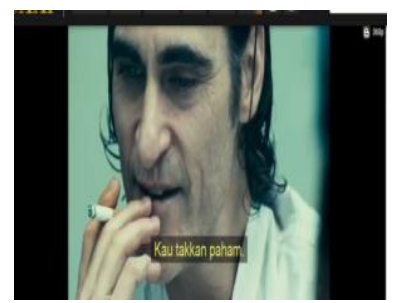

Sumber: Joker, 2019 Gambar 17. Scene 17

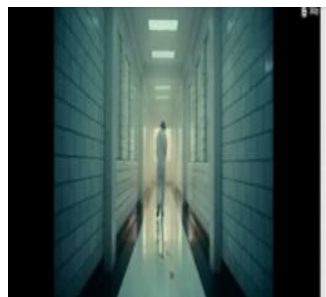

Gambar 18. Scene 18
Sumber: Joker, 2019

Diakhir kisah film Joker tersebut, pada gambar 17, ditampilkan sosok Arthur yang tengan dipenjara dan mengalami masa rehabilitasi. Apa yang dirasakan dalam kesepian yang mendalam dengan perbuatan- perbuatan yang dilakukan terhadap orang lain. Arthur menegaskan bahwa orang lain tidak akan paham tentang kesepian yang dihadapi dalam mengatasi masalah- masalah kehidupannya. Pada potongan terakhir, gambar 18, disana di tampilkan sosok Arthur yang telah melakukan tindakan pembunuhan lagi. Ia membunuh psikiater yang merawatnya karena menurut ia, psikiater tersebut tidak akan dapat menolong dirinya untuk dapat mengatasi kesepiannya.

Melihat lebih jauh mengenai kesepian yang dihadapi oleh Arthur sebagaai pemeran Joker, dan kita yang mengalaminya sebagai manusia. Serta bagaimana tindakan yang dapat dilakukan untuk mengatasi dan berdamai dengan kesepian tersebut. Disini akan di uraikan kembali dalam usaha untuk memperjelas dan mempertegas mengenai hal- hal yang berkaitan dengan seluk- beluk komunikasi interpersonal terlebih dahulu. Hal mendasar dalam memahami komunikasi interpersonal dalam kaitannya dengan usaha mengatasi dengan kesepian, yakni dengan mengenali elemenelemen yang terdapat dalam tindakan komunikasi intrapersonal sebagai benang merah untuk mengurai kesepian tersebut.

Tindakan dalam komunikasi intrapersonal mengedepankan tentang diri sendiri berlaku dan bertindak dalam mengatasi setiap kesulitan dan tantangan yang dihadapi. Oleh karena itu, komunikasi dengan diri sendiri perlu dilandaskan pada aspek- aspek diatas, sehingga dalam penerapannya memungkinkan manusia untuk lebih secara jujur terbuka, menerima keadaan diri dan lebih berani untuk menghadapi kesepian dalam hidupnya.

Rasa kesepian yang dialami oleh Arthur sebagai tokoh utama dalam film joker tersebut, terjadi atas rasa kesepian yang dialami dalam hidupnya. Bagaimana Arthur mengalami dilemma dalam hidup dan dirinya kemudia bagaimana kendala yang ia hadapi untuk menerima kenyataan 
hidup dalam hidupnya. Realita kehidupan yang ditampilkan di film tersebut seakan- akan menegaskan kembali secara nyata, bahwa setiap manusia menghadapi masalah dalam hidupnya, manusia perlu secara bijak mengambil jarak untuk melakukan komunikasi dengan dirinya. Artinya, manusia perlu mendiskusikan terlebih dahulu tentang bagaimana ia bersikap dan bertindak untuk mengatasi masalah hidupnya. Kenyataan bahwa Arthur mengalami kesepian, dipertegas dan dikuatkan oleh gangguan kejiwaan yang dia alami, tak tidak mampu diterima olehnya. Arthur selalu mencari penyebab dimasa lalunya. Pengalamanpengalaman masa lalunya membawa dirinya pada rasa depresi yang akut. Sehingga, ia tidak dapat mengendalikan dan mengatur tingkah lakunya. Kita bisa kehilangan kesadaran kita atas perbuatan- perbuatan kita. Tindakan menyakiti diri sendiri, tertawa, membunuh dan bahkan menyakiti orang lain yang tak berdosa. Pada taraf ini, dalam film Joker, kita melihat Arthur adalah sosok gambaran keluarga yang mengalami kesepian. Dia mengalami depresi. Arthur adalah seorang pelaku kejahatan yang lahir dari penderitaan. Semenjak Arthur diadopsi oleh ibu angkatnya yang juga mengalami delusi. Tindakan kekerasan fisik dan mental sudah menjadi bagian dalam kehidupannya. Kekejaman orang tua angkatnya, yang juga memiliki kehilangan kewarasan, mendorong Arthur bertindak diluar batas kemanusiaan.

Berdasarkan penjelasan pada paragraf sebelumnya. Terdapat beberapa poin penting yang dapat dijadikan benang merah dalam mengatasi kesepian, dengan berlandaskan konteks komunikasi intrapersonal. Argumentasi yang dapat penulis paparkan, yakni bahwa kesepian bisa menjadi satu satu bentuk jalan hidup manusia yang dapat membawa makna, sekaligus membentuk kepribadian diri dalam membangun dan mengupayakan kebahagiaan.

Dalam tindakan komunikasi intrapersonal, sebagai pelaku komunikasi. Berusaha mendamaikan diri dengan diri sendiri sekaligus melihat ini sebagai peluang untuk berubah adalah suatu pijakan tersendiri dalam melihat situasi yang dihadapi oleh semua pelaku kehidupan.

Hal ini dapat diuraikan dan dijelaskan dalam beberapa hal; Pertama, Rasa kesepian yang dialami oleh Arthur sebagai joker, dan kita ketika berhadapan dengan aneka permaslahan dan kebuntuan dalam hidup. Rasa kesepian bisa dijadikan sebagai waktu yang tepat untuk berpikir ulang tentang hidup kita. Kesepian adalah waktu untuk melakukan refleksi terhadap diri sendiri. membangun komunikasi yang jujur dan terbuka dengan diri sendiri. melalui diri sendiri, kita diajak untuk terbuka mengakui, mengenal serta melihat apa yang sudah, belum dan tengah kita lakukan serta kerjakan. Tindakan keterbukaan secara mendalam dengan diri sendiri ini perlu sehingga kita bisa melihat kesepian sebagai sebuah point balik untuk mengembangkan diri kitai. Kita juga diajak untuk berpikir lebih komprehensif, apa yang akan kita lakukan dengan berpijak pada kesepian yang kita rasakan sekarang ini dan disini.

Hal selanjutnya. Kedua, Didalam kesepian yang juga dialami oleh Arthur, pada gambar 1,2, 4,6,7 dan 8 dapat dipergunakan untuk melakukan tinjauan ulang secara mengena pada diri. Hal apa 
yang sesungguhnya penting dalam hidup kita? Apa tujuan hidup kita? Atau, hidup kita mau diarahkan kemana. Dalam kesepian, kita diajak untuk duduk bersama dengan kesepian itu untuk memikirkan ulang, mengkaji kembali apa yang sungguh bermakna dan menjadi orientasi mendasar di dalam hidup kita. Sehingga didalam kesepian itu, kita dipantaskan untuk kembali bangkit dan layak untuk mengejar cita- cita kita kembali. Walaupun jujur disadari, hal tersebut sulit. Kita juga diajak untuk melepaskan apa yang tidak otentik dan "membunuh" kita perlahanlahan. Kesepian membuat kita sadar dan fokus pada apa yang sungguh penting dalam hidup kita, dan membuang jauh-jauh hal-hal yang buruk dan menghancurkan harmonisasi tatanan hidup kita secara signifikan.

Bercermin pada kenyataan dalam kehidupan manusia. tugas manusia yang memiliki kesadaran dan kepekaan yang tinggi, maka manusia perlu untuk memiliki pemahaman yang jelas dengan apa yang ingin dicapainya dalam kehidupan ini. Manusia perlu memiliki orientasi yang sungguhsungguh dapat dihidupinya dengan berlandaskan pada pemahaman dan pengenalan pada diri sendiri (Marta, 2017:119).

Ketiga, kesepian yang dialami Arthur dalam film Joker, mendidik dan juga mengajak kita berpikir ulang tentang mereka yang ada disekitar kita. Tentang orang-orang yang berhubungan dan berdekatan dengan hidup kita. Kita diajak untuk sungguh jeli membedakan antara sahabat dan teman/parasit. Sahabat yang baik, akan hadir dan menemani kita di waktu kesepian. Sementara, teman/parasit hanya akan tertawa saja dan tidak menolong. Dalam situasi yang demikian, kita lalu bisa sungguh fokus pada sahabat kita yang, walaupun sedikit, akan selalu bisa menjadi pilar penyangga dalam hidup kita. Sama seperti yang Arthur lakukan, ia tidak membunuh sahabatnya yang memiliki tubuhnya yang kecil, karena dinilai baik dan dapat dijadikan temen. Sementara temannya yang memberinya senjata, ketika Arthur menghadapi masalah pemecatan, ia hanya mentertawakan saja, menghina dan menyudutkannya. Hingga pada suatu ketika, saat kesempatan itu ada, Arthur membalas dan membunuh temannya sendiri, karena menertawakan dirinya.

Maka, menjadi penting, bahwa kualitas hidup kita juga ditentukan oleh orang-orang yang ada di sekitar kita, yakni sahabat-sahabat kita. Maka, jangan pernah takut untuk kehilangan, mengalami perselisihan oleh teman. Setiap ketegangan yang ada antar teman merupakan saat yang baik untuk kita, agar dapat menjalin hal- hal yang positip kembali. Oleh karena itu ketidakcocokan dalam pertemanan, adalah bagian dari proses penyaringan untuk sungguh tahu, siapa sahabat sejati kita, baik sekarang ataupun nanti.

Keempat, dengan cara yang unik, kita dapat melihat kesepian. Kesepian juga dapat diapresiasi sebagai sebuah kesempatan kita untuk melihat dunia yang menjadi temapt kehidupan dengan perspektif yang berbeda. Di dalam kesepian seperti yang dialami Arthur, sesungguhnya bila kita dapat dengan baik mengontrol diri kita. Kesepian dapat membawa kita masuk dalam suatu keadaan gelap. Kita dipaksa untuk melepas semua pandangan dan keyakinan kita yang ada. Lalu, kita 
pun punya kesempatan untuk melihat dunia dengan cara yang sama sekali baru, dan mungkin lebih baik dari sebelumnya. Kesepian adalah saat untuk menjadi kreatif dan memiliki ide- ide yang dapat dipakai untk melihat situasi secara sadar keadaan yang tengah terjadi.

Kelima, dengan sudut pandang yang berbeda, kita lalu berpikir dengan cara yang berbeda. Kita pun lalu bisa bekerja dan berkarya dari sudut pandang yang berbeda. Inilah hakekat dari penemuan yang dapat menjadi sebuah terobosan baru yang bisa membawa manusia ke arah kehidupan yang lebih baik. Kesepian bisa dijejaki sebagai moment untuk menjadi acuan penemuan dan terobosan akan kebuntuan di dalam berbagai bidang sendi kehidupan manusia.

\section{SIMPULAN}

Melalui tokoh utama pada film Joker, konstruksi makna kesepian yang dilami oleh Joker dan oleh kita dengan cara terbarukan. Kesepian lalu tidak lagi dilihat sebagai penyakit. Kehidupan manusia didalam rutinitas yang dijalani sebagai makhluk sosial, ada kesedihan dan penderitaan di dalam kesepian. Oleh karena itu, jika tidak sikapi dan dimaknai dengan bijak, kesepian juga bisa menghancurkan dan merusak konsep diri manusia.

Kesepian juga dapat dilihat sebagai kesempatan untuk bangkit dan melakukan perubahan penting dalam hidup kita. Kesepian tidak perlu dilihat sebagai kegelapan, melainkan sebagai jalan hidup yang bisa ditempuh, guna menemukan makna dan kebahagiaan dalam hidup yang harus diperjuangkan terus menerus.
Begitu banyak orang-orang takut hidup dalam kesepian, yang merupakan tanda, bahwa mereka hidup dalam kesendirian. Jadi, orang takut dengan kesendirian. Argumen ini melupakan fakta, bahwa banyak orang yang berkeluarga, berkomunitas dan mereka yang tergabung dalam kelompokpun juga bisa merasakan kesepian.

Penelitian ini merekomendasikan bahwa pentingnya memahami komunikasi intrapersonal yang terjadi kepada manusia yang mengalami penyakit mental (mental illness) sehingga pemahaman dalam bentuk literasi mengenai mental illness dari berbagai prespektif bisa terbentuk.

\section{DAFTAR PUSTAKA}

Ahmed, A., \& Simmons, Z. (2013). Pseudobulbar affect : prevalence and management.

Therapeutics and Clinical Risk Management, 9, 483-489.

Arifin, S. (2016). Perkembangan Kognitif Manusia Dalam Perspektif Psikologi Dan Islam. Tadarus :Jurnal UM Surabaya, 50-67. Retrieved from file:///C:/Users/Acer/Downloads/350-978-1SM.pdf\%0Ahttp://journal.umsurabaya.ac.id/index.php/Tadarus/article/view/35 $0 / 261$

Fensi, F. (2018). FENOMENA HOAX: Tantangan terhadap Idealisme Media \& Etika Bermedia. Bricolage : Jurnal Magister Ilmu Komunikasi, 4(2), 133-209. https://doi.org/http://dx.doi.org/10.30813/bricola ge

Hidayati, D. S. (2015). SELF COMPASSION DAN LONELINESS. Jurnal Ilmiah Psikologi Terapan, 151(01), 154-164. https://doi.org/10.1145/3132847.3132886

Kristiyono, J., \& Sirikit, H. (2019). MENELISIK SIASAT CERITA DIGITAL REALITY PADA FILM READY PLAYER ONE ? Bricolage : Jurnal Magister Ilmu Komunikasi, 5(2), 159176. Retrieved from 
https://journal.ubm.ac.id/index.php/bricolage/arti cle/view/1657/1395

Marta, R. F. (2017). Esensi Dan Pemetaan Teoretisasi Media Komunikasi Dalam Perspektif Karl Marx. Bricolage: Jurnal Magister Ilmu Komunikasi, 2(02), 117-123.

https://doi.org/10.30813/bricolage.v2i02.839

Mulyana, D. (2013). Metodologi Penelitian Kualitatif. Paradigma Baru Ilmu Komunikasi dan Ilmu Sosial Lainnya. Bandung: Rosda Karya.

Nurayni, \& Supradewi, R. (2017). PERANTAU SEMESTER AWAL DI UNIVERSITAS DIPONEGORO THE CORRELATION BETWEEN SOCIAL SUPPORT AND SENSE OF BELONGING WITH. Jurnal Proyeksi, 12(2), 35-42.

Prasetya, A. B. (2012). THE DARK KNIGHT ( Studi Semiotik Tokoh Joker dalam Film The Dark Knight ). Jurnal Ilmiah Dan Komunikasi, 2(2), 72-79.

Puspasari, M. E. (2014). Psikologi Kognitif Dalam Proses Kreatif. ULTIMART: Jurnal Komunikasi Visual, V(01), 7-12.

Rubiyanto. (2018). STRATEGI MEMBIDIK KETERSEDIAAN AUDIENS DALAM INDUSTRI TELEVISI ( Studi Deskriptif Tayangan Film India ANTV ). Bricolage: Jurnal Magister Ilmu Komunikasi, 4(1), 83-94.

Sasongko, Y. P. D., \& Marta, R. F. (2018). Ekspresi identitas melalui relasi ayah dan anak pada iklan youtube grab official. Bricolage: Jurnal Magister Ilmu Komunikasi, 4(2), 118-132.

\section{Sibarani, R. C. O. (2013). KOMUNIKASI} INTRAPERSONAL DAN PERILAKU FOBIA (Studi Deskriptif Kualitatif Proses Komunikasi Intrapersonal Hipnoterapi dalam Mengubah Prilaku Fobia Klien di Klinik Tranzcare Jakarta). Journal of Chemical Information and Modeling, 53(9), 1-10.

https://doi.org/10.1017/CBO9781107415324.004

Strauss, A. (2015). Dasar-Dasar Penelitian KualitatifTata langkah dan Teknik- Teknik Teorisasi Data. Yogyakarta: Pustaka Belajar. 